\title{
Comprehensive Clinical and Social Research at the Moscow Research Institute of Psychiatry: Translation into Clinical Practice
}

\author{
Комплексные клинико-социальные исследования в Московском \\ научно-исследовательском институте психиатрии: трансляция \\ в клиническую практику \\ DOI:10.17816/CP95
}

Historical article

\begin{abstract}
Alexander B. Shmukler, Larisa G. Movina, Oleg O. Papsuev, Lyudmila I. Salnikova, Nina G. Shashkova, Elena M. Kiryanova

Moscow Research Institute of Psychiatry - branch of the Federal State Budgetary Organization, "V. Serbsky National Medical Research Centre for Psychiatry and Narcology" of the Ministry of Health of the Russian Federation
\end{abstract}

The article can be used under the CC BY-NC-ND 4.0 license (c) Authors, 2021

\author{
Александр Б. Шмуклер, Лариса Г. Мовина, \\ Олег О. Папсуев, Людмила И. Сальникова, \\ Нина Г. Шашкова, Елена М. Кирьянова \\ Московский научно-исследовательский \\ институт психиатрии - филиал ФГБУ «НМИЦ ПН \\ им. В.П. Сербского» Минздрава России
}

Лицензия CC BY-NC-ND 4.0

(C) Коллектив авторов, 2021

\begin{abstract}
The article is devoted to the work of the Moscow Research Institute of Psychiatry to improve psychiatric care for patients with psychotic disorders. An important feature of this work was an integrated approach, in which the clinical picture of the disease was assessed in close connection with the patient's personal and psychological characteristics, social conditions of his life, therapeutic opportunities, rehabilitation potential and organizational structure of care. The article reflects the results of many years of work of the department of outpatient psychiatry and the organization of psychiatric care under the guidance of Professor I.Ya. Gurovich. The results of scientific research carried out by the staff of the institute in a traditional humanistic manner are presented. The translational nature of the research is emphasized by its inextricable link with clinical and social approaches.

As a result of many years of work, a concept was developed to provide assistance to various groups of patients, starting with the first manifestations of the disease and ending with cases of long-term chronic disorders with a pronounced level of social maladaptation. As a result, a whole spectrum of new organizational forms of psychiatric care was proposed, such as departments (clinics) of the first psychotic episode, medical rehabilitation departments, assertive community treatment departments, designed for the most difficult patients. These organizational forms were fixed in the regulatory documents of the Ministry of Health and Social Development of the Russian Federation. To date, the above departments have been established in psychiatric institutions in many regions of the Russian Federation. Further development of this area is associated with neurobiological research to identify complex biomarkers of psychotic spectrum disorders.

Thus, the research carried out at the present time preserves the tradition of an integrated clinical and social approach to the study of mental disorders. It is shown that an important advantage of this approach is their translational nature.
\end{abstract}




\section{АННОТАЦИЯ}

Статья посвящена работе Московского научно-исследовательского института психиатрии по совершенствованию психиатрической помощи пациентам с психотическими расстройствами. Важной особенностью этой работы являлся комплексный подход, в котором клиническая картина заболевания оценивалась в неразрывной связи с личностными и психологическими характеристиками пациента, социальными условиями его жизни, терапевтическими возможностями, реабилитационным потенциалом и организационной структурой помощи. В статье приводятся результаты многолетней работы отдела внебольничной психиатрии и организации психиатрической помощи под руководством профессора И.Я.Гуровича. Представлены результаты научных исследований, выполненных сотрудниками института в традиционном гуманистическом ключе. Трансляционный характер исследования подчеркивается неразрывной связью с клиническими и социальными подходами.

В результате многолетней работы была разработана концепция оказания помощи различным группам пациентов, начиная с первых проявлений заболевания и заканчивая случаями длительно протекающих хронических расстройств с выраженным уровнем социальной дезапдаптации. В результате были предложен целый спектр новых организационных форм психиатрической помощи, таких как отделения (клиники) первого психотического эпизода, медико-реабилитационные отделения, отделения интенсивного оказания психиатрической помощи, предназначенные для наиболее тяжелого контингента пациентов. Данные организационные формы были закреплены в нормативных документах Министерства здравоохранения и социального Развития Российской Федерации. На сегодняшний день вышеперечисленные отделения созданы в психиатрических учреждениях в многих регионах РФ. Дальнейшее развитие данного направления связано с нейробиологическими исследованиями по выделению комплексные биомаркеров расстройств психотического спектра.

Таким образом, исследования, осуществляемые в настоящее время, сохраняют традицию комплексного клинико-социального подхода к изучению психических расстройств. Показано, что важным преимуществом данного подхода является их трансляционный характер.

Key words: translational psychiatry; psychosocial rehabilitation; biological research Ключевые слова: транслячионная психиатрия; психосоциальная реабилитация; биологические исследования

\section{INTRODUCTION}

Russian psychiatry from the beginning of its establishment as a scientific discipline was characterized by a holistic approach to the mental healthcare provision. An important characteristic of this approach was comprehensive consideration of clinical, psychological and social aspects, personality of the patient, along with the organization of treatment and rehabilitation issues. The clinical manifestation of the disease was assessed together with the patient's personality, psychological traits and social conditions, therapeutic opportunities, rehabilitation potential and organizational structure of care. Typical of Russian psychiatry as a whole, this approach has formed the basis of the scientific and practical activities of the Moscow Research Institute of Psychiatry (MRIP) since it came into being. The clinical approach has definitely been the "carte-de-visite" of the MRIP across the entire period of its existence and remains such at the present time.
Professor Lev Markovich Rozenstein, one of the first directors of the MRIP, is known as a major theorist of psychiatric care organization and an active adept of the rehabilitation approach in psychiatry. He was a brilliant clinician and a sophisticated diagnostician, developing concepts for the prevention of mental disorders, based on a deep understanding and the practical application of K. Jaspers' phenomenological method. ${ }^{1}$ His statements that hospitalizations alone cannot solve the problems of mental patients sound surprisingly modern. In his view, it is necessary to go beyond hospital psychiatry, especially since the majority of psychiatric patients will always remain in the community. The preventive approach in psychiatry, inextricably associated with outpatient psychiatric care, according to L.M. Rozenstein, was based on a comprehensive assessment of the patients' condition (and not only the sum of certain symptoms of the disease) and a subtle analysis of the actual disease manifestations 
together with dynamics of the patient's personality in a social environment.

L.M. Rozenstein's ideas were reflected in the concept of social and vocational rehabilitation of patients with schizophrenia, which was actively developed in Russian psychiatry between the 1950s and the 1970s. Here we can highlight the studies of Professor Dmitry Evgenievich Melekhov, ${ }^{2}$ in which special attention was paid to the concept of "defect", understood as persistent, postpsychotic manifestations not limited by negative symptoms, but rather possessing a certain structure, clinical features and dynamics.

D.E. Melekhov was the head of the MRIP in the 1950s and is one of the founders of the vocational rehabilitation system in the Soviet Union. Understanding the working capacity prognosis in his studies is inextricably associated with clinical indicators, using both static and dynamic characteristics (systematics of schizophrenia forms according to the "cross section" and "longitudinal section"), as well as post-psychotic states. ${ }^{2}$

In this regard, D.E. Melekhov singled out the period of defect development at the active disease stage, the period of formation and stabilization of the defect, as well as the period of the formed and compensated defect. At the same time, even in the latter case, the defect was not considered as being stiff condition, on the contrary, the dynamics of the formed, defective conditions in the guise of episodic, short-term inadequate mood and activity fluctuations, reactive states and the pathological development of the post-psychotic personality were indicated. Moreover, possibility of the compensation, subcompensation (labile and incomplete compensation) and defect decompensation were discussed. The need to distinguish between reactions developing during the active course of the disease and the reactions that generate new symptoms of the disease from truly compensatory reactions, were emphasized.

Based on the peculiarities of the clinical picture and the dynamics of the defect (which is much broader than negative disorders sometimes synonymously used in these cases), the tactics of social and labour recovery of patients were established. Indeed, it is important to distinguish between the restoration of social functioning, due to the symptoms regression in the active stage of the disease and the patient's adjustment due to the defect compensation in the post-psychotic period. At the same time, the importance of purposeful activity of the individual and the significance of the environment in the compensation of defect were emphasized. ${ }^{2}$

The purpose of this article is to review the clinical and social research conducted at the Moscow Research Institute of Psychiatry, and implementation of their results in clinical practice.

\section{NEW APPROACHES TO THE MENTAL HEALTHCARE IN THE COMMUNITY}

Professor Isaac Yakovlevich Gurovich also used an integrated approach to the rehabilitation of patients with mental illnesses. In 1978 as the head of the Outpatient Psychiatry and Organization of Mental Healthcare Department, he placed this clinical approach at the forefront of organizational healthcare in psychiatry. New organizational forms of mental care were filled in with clinical content; they were based on the understanding of the dynamic nature of psychiatric diseases, that determines the patients ' social functioning. ${ }^{3}$

The system of treatment in day hospitals using stepwise approach and continuity of care was developed in the department. The development of the treatment approaches for subacute, subpsychotic conditions, the so-called "outpatient exacerbations" appeared to be a significant achievement. ${ }^{4}$ The dissertation researches performed in the department formed the basis for the Regulation on day hospitals, which laid the foundation for the further development of the psychiatric service, with a shift to outpatient care, and for the organization of new forms of care provision within the service. A detailed development of clinical and social indications and contraindications for the admission, significantly increased the scope of conditions that can be treated in day hospitals and enabled patients with psychotic disorders, who maintain socially acceptable behavior and have the support of their family, ${ }^{5}$ to receive treatment there. Other substitute forms of hospital care have been developed, such as home inpatient care. ${ }^{6}$

The essential role of psychosocial therapy and psychosocial rehabilitation as an obligatory component of psychiatric care at any stage of its provision including a day hospital, ${ }^{7}$ was emphasized together with the importance of adequate and intensive psychopharmacotherapy. An important administrative decision - the introduction of social workers into the staff of psychiatric institutions and their subdivisions (psychiatric hospitals, day hospitals, neuropsychiatric 
dispensaries), enshrined in the corresponding order of the Ministry of Health, was the logical result of this work and significant achievement of the department. This laid the foundation for comprehensive, polyprofessional healthcare for mentally ill. An important aspect of this approach was the consideration of psychosocial interventions not only as a tool to facilitate social adjustment, but also as an effective method of treatment.

The work of outpatient psychiatric facilities has significantly changed and their services have been tailored to the needs of the patients. The modern management of psychiatric patients in the dispensary was laid, the criteria for dispensary observation and the indications for withdrawal from it were developed and implemented. ${ }^{8}$

One of the research directions of the department were the issues of social adjustment and the rehabilitation of patients with chronic schizophrenia, which made up a significant part of the dispensary contingent. The features of clinical manifestations and social adjustment of patients with schizophrenia were studied at the stage of disorder stabilization, in an outpatient setting. As a result, a close relationship was highlighted between the clinical manifestations of the disease, forms of social adjustment and the conditions conducive to successful rehabilitation. ${ }^{9,10}$

It should be emphasized that all studies put the clinical approach at the forefront, based on a subtle diagnostic assessment of the patient, including both psychopathological analysis and the dynamics of the disease, as well as personality, psychological and social characteristics. For the first time in Russian psychiatry, the concept of quality of life was introduced into the analysis of the patients' condition; its features were described in various groups of patients, as well as its importance for social adjustment and psychosocial treatment and rehabilitation. ${ }^{11}$

The pharmacoepidemiological and pharmacoeconomic aspects of the psychiatric care for patients with schizophrenia were studied for the first time. ${ }^{12}$

The Russian-Canadian disability program (19972007), which was organized by the staff of the Department of Outpatient Psychiatry and Organization of Mental Healthcare of the MRIP and the Department of Community Rehabilitation and Disability Studies at the University of Calgary (Canada) was the next step in the development of the clinical and social directions in psychiatry. The principles of psychosocial therapy and rehabilitation, the interprofessional team management of patients, as well as individual case management were developed within the framework of the Russian-Canadian program. The staff of the Department scientifically substantiated the efficiency of methods, widely known abroad such as psychoeducation, compliance therapy and the training of social and cognitive skills.

The long-term cooperation of the Department with the University of Calgary facilitated the development of joint educational programs, a large number of specialists from the regions of Russia were trained in psychosocial therapy and the rehabilitation of patients, including internships in Canada. Together with the Moscow State Social University (MSSU), the course for social workers, "Social work in psychiatry", was developed.

\section{CARE SYSTEM FOR SPECIAL PATIENT GROUPS}

A further development of the concept of psychosocial therapy and rehabilitation led to the study of clinical and social characteristics and the identification of the special needs of various groups of patients with schizophrenia. One of the most important areas of research was the study of the initial stages of psychotic spectrum disorders and, on this basis, the development of scientificallygrounded practical approaches to organizing care for patients with newly emerging psychotic conditions. Along with detailed descriptions of the clinical picture and therapeutic approaches in care, considerable attention was paid to the clinical and organizational aspects. As a result, the principles underlying the work of first episode psychosis departments (clinics), were established. After a series of educational seminars, similar clinics were opened in more than 30 regions of the Russian Federation. In fact, a reference system of mental healthcare at the initial stages of psychotic spectrum disorders was developed, including not only inpatient and day hospital treatment, but also the longterm follow up of patients. Its efficiency was proved, both from a clinical point of view and the social recovery of patients. ${ }^{13-15}$

Along with the first psychotic episode, considerable attention was paid to the study of the clinical features and the social functioning of patients with a chronic course of the disease, frequent and prolonged hospitalizations, as well as those who had lost social ties. ${ }^{16,17}$ The efficiency of the complex community therapy of schizophrenic 
patients, discharged after long-term hospitalizations, has been demonstrated, which, along with active pharmacotherapy, should include the psychoeducation of patients and their relatives, as well as training in selfcare and independent living skills. ${ }^{18,19}$ The efficiency of special rehabilitation programs was investigated using the example of the "Club House" model. ${ }^{20}$ Various groups of patients with schizophrenia and schizophrenia spectrum disorders, receiving care as outpatients, were studied. The principles of complex community-based psychosocial therapy and rehabilitation were developed and implemented for each of these groups. ${ }^{21-23}$

An important element of the department's scientific activity was the study of socially vulnerable groups of patients with schizophrenia, and the development of adequate organizational forms of mental healthcare, tailored to their needs. These groups included patients with unstable social and labour adaptation, with frequent and very frequent hospitalizations, as well as lonely patients. ${ }^{24-28}$

The work was carried out in two directions: on the one hand, the psychological components surrounding the issues of loneliness, the disability of patients with schizophrenia and the stigma of mental illness were investigated and the main "targets" of psychosocial interventions for these patients were identified;29,30 on the other hand, the efficiency of psychosocial work with this group of patients was demonstrated with the involvement of community resources, namely, the integrated social services centres. ${ }^{31}$ The study of the social environmental factors and the immediate surroundings of patients with schizophrenia made it possible to develop and put into practice the methods of work with the family of patients with mental illnesses, known as compliance therapy. ${ }^{32}$

An important milestone in the development of community-based psychiatry was the organization of Russia's first association of psychiatric care consumers and their relatives, called "New Choices", with branches in more than 50 regions of the country. ${ }^{33}$ This organization is now known as the All-Russian Public Organization of People with Mental Disabilities.

Such forms of transdisciplinary collaboration of psychiatric institutions, social protection services and public institutions, aimed at the re-integration of patients with mental illnesses into society, are now an essential part of community-oriented psychiatry.

\section{CONCLUSION}

Thus, as a result of longstanding work, the concept of care for various groups of patients was developed, starting with the first manifestations of the disease and ending with cases of long-term, chronic disorders with a pronounced level of social maladjustment. As a result, a broad spectrum of new organizational forms of mental healthcare was proposed. In addition to the aforementioned first episode psychosis clinics, ${ }^{34}$ medical rehabilitation departments (operating both within a hospital and in the community) were proposed and put into practice. Staffing, objectives, indications for referral and the methodology of work were developed. Furthermore, a completely new form of care for Russian psychiatry - intensive care departments for patients with the most severe symptoms, receiving care in a day hospital - was introduced. ${ }^{35-37}$ These organizational forms were statutory enshrined in the Order of the Ministry of Health and Social Development of the Russian Federation No. 566n, "On approval of the procedure of medical care provision for mental and behavioral disorders", dated May 17th, 2012. To date, the aforementioned departments have been established in psychiatric services in many regions of the Russian Federation.

All these new organizational forms of psychiatric care are characterized by a significant proportion of psychosocial therapy and rehabilitation within the treatment course. This approach is based on a thorough study of psychosocial intervention targets and their therapeutic mechanisms. In this regard, the study of cognitive impairments in psychotic spectrum disorders, which play a decisive role in the social functioning, is essential.

The features of neurocognitive deficit and its dynamics were described in detail among patients with schizophrenia and schizophrenia spectrum disorders at different stages of the disease, and depending on the course type. ${ }^{38-41}$ Much attention has been paid to the studies of social cognitive functions, resulted in development of the whole range of new pathogeneticoriented approaches to psychosocial therapy. ${ }^{42,43}$ An investigation into the negative symptoms of schizophrenia and their relationship with cognitive functioning has been carried out; new tools are being validated to assess social cognitions and negative symptoms. ${ }^{44,45}$ The latest forms of cognitive remediation are tested in clinical units 
(first episode psychosis clinic, medical rehabilitation department). Methodological developments in this direction have contributed to the introduction of a number of modern training programs into the practice, such as training on cognitive and social skills, ${ }^{46}$ motivational training for patients with schizophrenia ${ }^{47}$ and metacognitive training for patients with psychosis. ${ }^{48,49}$

The further development is associated with neurobiological studies, aimed at the identification of complex biomarkers for diagnosistics and determination of biopsychosocial intervention tactics. This refers to the study of evoked potentials, in particular, the study of facial expressions, ${ }^{52-55}$ the study of oculomotor alterations in patients with schizophrenia spectrum disorders ${ }^{56}$ and autoimmune disorders in newly emerging psychotic states. ${ }^{56-59}$ In general, the task is to carry out a network analysis of the identified disorders. ${ }^{60-62}$

Thus, the research carried out at the present time preserves the tradition of an integrated clinical and social approach, on the basis of which organizational models of psychiatric services are proposed. An important advantage of this approach is the applicability of its results in healthcare practice, that is, the translational nature of scientific studies.

\section{Manuscript process:}

Submitted: 15.07.2021

Accepted: 26.08.2021

Published: 30.09 .2021

Funding: The research was carried out without additional funding.

Conflict of interests: The authors report no conflicts of interest.

Authors" contribution: A.B. Shmukler, L.G. Movina, O.O. Papsuev - design, publication review, writing an article; L.I. Salnikova, N.G. Shashkova, E.M. Kiryanova writing an article..

\section{Correspondence to:}

\section{Prof. Alexander Shmukler, MD}

shmukler.a@serbsky.ru

\section{For citation:}

Shmukler AB, Movina LG, Papsuev OO, Salnikova LI, Shashkova NG, Kiryanova EM. Comprehensive clinical and social research at the Moscow Research Institute of Psychiatry: translation into clinical practice. Consortium Psychiatricum. 2021;2(3):45-52. DOI:10.17816/CP95

\section{References}

1. Melekhov DE, Grosman AV. L.M. Rozenshtein and the period of formation of Soviet social psychiatry. In Semenov S.F. ed. Clinical aspects of social rehabilitation of mentally ill patients. Proceedings of the Institute of Psychiatry Vol.73; Moscow Research Institute of Psychiatry under the Ministry of Health of RSFSR; 1976.

2. Melekhov DE. Clinical basis for prognosis of work capacity in schizophrenia. Moscow: Med-giz; 1963.

3. Gurovich IYa. On clinical and social criteria for the removal from the dispensary registration of patients with schizophrenia - the final act of social rehabilitation. Questions of the organization of psychiatric care. Moscow; Moscow Research Institute of Psychiatry under the RSFSR Ministry of Health; 1982.

4. Gurovich IYa, Sarkisyan W, Kutsay SI. Subacute conditions in schizophrenia in outpatient practice. Early rehabilitation of mentally ill. Leningrad; Leningradsky Research Psychoneurology Institute, 1984.

5. Sarkisyan VV. Subacute conditions in schizophrenia, their clinic and features of treatment in a day hospital. Dissertation. Moscow Research Institute of Psychiatry under the Ministry of Health, 1983.

6. Aliskhanov MA. Treatment of patients with schizophrenia in a homehospital (organizational, clinical and economic aspects). Dissertation. Moscow Research Institute of Psychiatry under the Ministry of Health of Russian Federation, 2005.

7. Gurovich IYa, Shmukler AB, Storozhakova YaA. Psychosocial therapy and psychosocial rehabilitation in psychiatry. Medpraktika-M; 2004

8. Lyubov EB. Clinical and social criteria for determining the type of apparent recovery outcomes in schizophrenia (issues of removal from dispensary registration). Dissertation. Moscow Research Institute of Psychiatry under the Ministry of Health of RSFSR; 1987.

9. Gurovich IYa, Visnevskaya LYa, Shashkova NG, Khudaverdiev VV. Features of the clinic and social adaptation of patients with schizophrenia at the stage of stabilization (based on outpatient practice). In: Smulevich AB, ed. Schizophrenia and schizophrenia spectrum disorders. Moscow; RAMS MHRC. 1999:77-97.

10. Salnikova LI. Patients with paranoid schizophrenia with persistent adaptation in an outpatient setting. Dissertation. Moscow Research Institute of Psychiatry under the RF Ministry of Health; 1995.

11. Shmukler AB. Social functioning and quality of life of the mentally ill. Doctoral thesis in Russian. Moscow Research Institute of Psychiatry under the RF Ministry of Health; 1999.

12. Lyubov EB. Pharmaco-epidemiologic and pharmacoeconomic aspects of mental healthcare for patients with schizophrenia. Doctoral thesis in Russian. Moscow Research Institute of Psychiatry under the RF Ministry of Health; 2002.

13. Movina LG. Psychosocial treatment of patients with schizophrenia and schizophrenia spectrum disorders with early psychotic episodes. Dissertation. Moscow Research Institute of Psychiatry under the RF Ministry of Health; 2005.

14. Dorodnova AS. Clinical, social and organizational aspects of psychiatric care for patients with schizophrenia and schizophrenic spectrum 
disorders with early psychotic episodes. Dissertation. Moscow Research Institute of Psychiatry under the RF Ministry of Health; 2006.

15. Bessonova AA. The first episode of schizophrenia: clinical, social and pharmacoeconomic aspects. Dissertation. Moscow Research Institute of Psychiatry under the RF Ministry of Health; 2008.

16. Gebel KM. Dynamics of clinical and medico-psychological characteristics in the process of rehabilitation of patients with schizophrenia who have lost their social connections. Dissertation. "St. Petersburg Research Psycho-Neurological Institute named after V. M. Bekhterev of the Federal Agency for Health and social development of the Russian Federation "; 2009.

17. Alsakov AA. Patients with schizophrenia with frequent hospitalizations: clinical, social and pharmacoeconomic aspects of anti-relapse therapy with deposited forms of antipsychotics. Dissertation. Moscow Research Institute of Psychiatry under the RF Ministry of Health; 2003.

18. Shashkova NG, Babushkina El. Patients with schizophrenia with frequent and prolonged hospitalizations and the prospects for them of alternative forms of care. Article in Russian. Social and Clinical Psychiatry. 2003;13(2):107-111.

19. Davydov KV. Patients with schizophrenia with repetitive prolonged hospitalizations (clinical and social characteristics and integrated community mental healthcare after discharge from hospital). Dissertation. Moscow Research Institute of Psychiatry under the RF Ministry of Health; 2005.

20. Donenko IE, Shashkova NG, Veschugina TS. Evaluation of the effectiveness of the "Club House" rehabilitation program. Article in Russian. Social and Clinical Psychiatry. 2000;10(4):40-45.

21. Bugrova EI. Noncompliance with the regimen of outpatient psychopharmacotherapy in patients with schizophrenia: clinical, social and economic aspects. Dissertation. Moscow; 2007.

22. Vasilyeva EA. Comprehensive psychosocial care for patients with schizophrenia and schizophrenic spectrum disorders with a high, not due to clinical indications, referral to psychiatric institutions. Dissertation. Moscow Research Institute of Psychiatry under the RF Ministry of Health; 2006.

23. Shenderov KV. Clinical and social aspects of care for patients with schizophrenia and schizophrenic spectrum disorders in a day hospital of a psychiatric dispensary. Dissertation. Moscow Research Institute of Psychiatry under the RF Ministry of Health; 2011.

24. Kiryanova EM. Schizophrenia patients with unstable employment adaptation as a group disability risk. Article in Russian. Social and Clinical Psychiatry. 1993;3(1):29-33.

25. Kiryanova EM. Schizophrenia patients with unstable employment adaptation. Dissertation. Moscow Research Institute of Psychiatry under the RF Ministry of Health; 1994.

26. Papsuev OO, Movina LG, Kouznetsova OG, Levina NB. Supported Employment Program Trial Within Rehabilitation Unit. Article in Russian. Social and Clinical Psychiatry. 2019;29(1):32-39.

27. Kiryanova EM, Salnikova LI. New approaches to the organization of outpatient care for lonely patients with schizophrenia. Article in Russian. Social and Clinical Psychiatry. 2000;10(1):21.

28. Kiryanova EM, Tkachev DYu. Psychiatric care for patients with schizophrenia and schizophrenic spectrum disorders with ultrafrequent hospitalizations and its comparative effectiveness. Article in Russian. Social and Clinical Psychiatry. 2011;21(4):47-50.

29. Gurovich IYa, Kiryanova EM. On the program to combat stigma associated with schizophrenia. Article in Russian. Social and Clinical Psychiatry. 1999;9(3):5-8.

30. Semenova ND. Psychological and social factors of disability.Article in Russian. In: Current Trends And New Service Models In Mental Healthcare. Medpraktika-M; 2007:147-162.
31. Papsuyev OO, Visnevskaya LY, Shevchenko VA. Interaction Between Psychiatric Service And Social Care Center. Article in Russian. Social and Clinical Psychiatry. 2008;18(4);69-72.

32. Rivkina NM, Salnikova LI. Working with families in the system of psychosocial therapy for patients with schizophrenia and schizophrenia spectrum disorders with first psychotic episodes. Article in Russian. Social and Clinical Psychiatry. 2009;19(1):65-75.

33. Lyubimova GYu, Levina NB. On the all-Russian society of persons with Mental Health Disabilities and their Families "New Choices". Article in Russian. Social and Clinical Psychiatry. 2014;24(4):107-108.

34. Gurovich IYa, Shmukler AB, ed. First psychotic episode (problems and mental healthcare). Medpraktika-M; 2010.

35. Utkin AA. New forms of mental healthcare as part of the system of complex psychosomal therapy and psychosocial rehabilitation. Dissertation. Moscow Research Institute of Psychiatry under the RF Ministry of Health; 2009.

36. Limankin OV. The system of psychosocial care in a psychiatric hospital for patients with long-term hospitalizations. Dissertation. Moscow Research Institute of Psychiatry under the RF Ministry of Health; 2007.

37. Stepanova ON. Comprehensive polyprofessional care for patients with schizophrenia and schizophrenia spectrum disorders in the department of assertive (intensive) community treatment. Dissertation. Moscow Research Institute of Psychiatry under the RF Ministry of Health; 2009.

38. Gurovich IYA, Shmukler AB, Zaytseva YuS. Dinamika neyrokognitivnogo funktsionirovaniya bol'nykh na nachal'nykh etapakh razvitiya shizofreniyi i rasstroystv shizofrenicheskogo spektra. Article in Russian. Zhurn nevrologiyi i psikhiatriiyi, SS Korsakova. 2012;112(8):7-14.

39. Zaitseva YuS. The first psychotic episode: a five-year follow-up clinical neuropsychological study. Dissertation. Moscow Research Institute of Psychiatry under the RF Ministry of Health; 2010.

40. Magomedova MV, Correlation of social functioning and neurocognitive deficit in patients with schizophrenia and schizoaffective disorder in the early and late stages of the disorder. Dissertation. Moscow Research Institute of Psychiatry under the RF Ministry of Health; 2003.

41. Shmukler AB, Semenkova EA. Age features of neurocognitive deficit in patients with schizophrenia and schizophrenia spectrum disorders at the initial stages of the disorder. Article in Russian. Social and Clinical Psychiatry. 2013;23(4):19-23.

42. Gurovich IY, Papsuev OO, Shmukler AB, et al. Cognitive bias salience in patients with schizophrenia in relation to social functioning: A four-case observation study. Psych J. 2016;5(1):3647. doi:10.1002/pchj.126.

43. 43. Gurovich IYa, Papsuev OO, Minyaicheva MV, Movina LG. Social cognition in schizophrenia and schizophrenia-spectrum disorders. Article in Russian. Doctor.ru. 2014;6-1(84):81-87.

44. 44. Faerden A, Lyngstad SH, Simonsen C, et al. Reliability and validity of the self-report version of the apathy evaluation scale in first-episode Psychosis: Concordance with the clinical version at baseline and 12 months follow-up. Psychiatry Res. 2018;267:140147. doi:10.1016/j.psychres.2018.05.065.

45. Mucci A, Vignapiano A, Bitter I, et al. A large European, multicenter, multinational validation study of the Brief Negative Symptom Scale. Eur. Neuropsychopharmacol. 2019;29(8):947-959. doi:10.1016/j.euroneuro.2019.05.006.

46. Kholmogorova AB, Garanyan NG, Dolnykova AA, Shmukler AB. Cognitive and social skills training (CSST) program for patients with schizophrenia. Social and Clinical Psychiatry. Article in Russian. 2007;17(4):67-77. 
47. Semenova ND, Gurovich IYa. The module for the formation of motivation for the rehabilitation in patients with schizophrenia and schizophrenia spectrum disorders. Article in Russian. Social and Clinical Psychiatry. 2014;24(4):31-36.

48. Papsuev OO, Movina LG, Minyaicheva MV. Metacognitive training for patients with schizophrenia and schizophrenic spectrum disorders.Article in Russian. Social and Clinical Psychiatry. 2014;24(3):33-36.

49. Moritz S, Woodward TS. Metacognitive training in schizophrenia: from basic research to knowledge translation and intervention. Curr Opin Psychiatry. 2007;20(6):619-625. doi:10.1097/ YCO.0b013e3282f0b8ed.

50. Zaytseva Y, Garakh Z, Novototsky-Vlasov V, et al. EEG coherence in a mental arithmetic task performance in first episode schizophrenia and schizoaffective disorder. Clin Neurophysiol. 2018;129(11):2315-2324. doi:10.1016/j.clinph.2018.08.020.

51. Garakh ZV, Zaitseva YS, Novototskii-Vlasov VY, et al. Effects of Instructions on the Early Stages of the Visual Perception of Verbal Stimuli in Health and Schizophrenia. Neuroscience and Behavioral Physiology. 2018;48(4):463-473. doi:10.1007/s11055-018-0587-3.

52. Murashko AA. Neurophysiological aspects of face perception in patients with schizophrenia spectrum disorders.Article in Russian. Social and Clinical Psychiatry. 2018;28(3):87-91.

53. Spektor VA. Facial affect recognition impairments in schizophrenia and schizoaffective disorder (clinical and neurophysiological aspects): design of the study. Article in Russian. Social and Clinical Psychiatry. 2020;30(2):15-21.

54. Spector VA, Mtskanyan EV, Shmukler AB. P100 and N170 changes in perception of facial expression in patients with schizophrenia and schizoaffective disorder. Article in Russian. Russian Psychiatric Journal. 2020;(6):82-92.
55. Murashko AA, Shmukler A. EEG correlates of face recognition in patients with schizophrenia spectrum disorders: A systematic review. Clin Neurophysiol. 2019;130(6):986-996. doi:10.1016/j. clinph.2019.03.027.

56. Sukhachevsky IS, Anisimov VN, Latanov AV, Shmukler AB. Oculomotor disorders in patients with schizophrenia. Article in Russian. Social and Clinical Psychiatry. 2018;28(1):83-89.

57. Shmukler AB, Ivashkina AA, Murashko AA. A case of anti-NMDA receptor encephalitis with a clinical picture of febrile catatonia. Bulletin of Siberian Medicine. 2019;18(4):266-272.

58. Murashko AA, Kiryanova EM, Salnikova LI, Spektor VA. Clinical and epidemiological features of psychotic spectrum disorders associated with NMDA receptor antibodies: study protocol. Article in Russian. Social and Clinical Psychiatry. 2020;30(3);37-42.

59. Murashko AA, Pavlov KA, Pavlova OV, Gurina OI, Shmukler A. Antibodies against N-Methyl D-Aspartate Receptor in Psychotic Disorders: A Systematic Review. Neuropsychobiology. 2021:1-18. doi:10.1159/000515930.

60. Karyakina MV, Shmukler AB. Network analysis as a new research approach in psychiatry. Psychiatry and psychopharmacotherapy. 2020;(5):4-8.

61. Karyakina MV, Shmukler AB. Neurocognitive impairments in patients with schizophrenia and schizophrenia spectrum disorders: cluster analysis results. VM Bekhterev Review of Psychiatry and Medical Psychology. 2020(1):45-51. doi:10.31363/2313-70532020-1-45-51.

62. Shmukler AB, Kostyuk GP, Latanova AV, Sidorova MYu, et al. Network analysis of cognitive, oculomotor and speech indicators in schizophrenia. Article in Russian. S.S. Korsakov Journal of Neurology and Psychiatry. 2020;120(5)-2:54-60. 